\title{
Requirements for zero energy balance of nonlactating, pregnant dairy cows fed fresh autumn pasture are greater than currently estimated
}

\author{
K. S. Mandok, ${ }^{1}$ J. K. Kay, ${ }^{*}$ S. L. Greenwood,†‡ G. R. Edwards, $\ddagger$ and J. R. Roche ${ }^{*}$ \\ *DairyNZ, Private Bag 3221, Hamilton 3240, New Zealand \\ †Department of Animal Science, University of Vermont, Burlington 05405 \\ ¥Faculties of Agriculture and Life Science, Lincoln University, Lincoln 7647, New Zealand
}

\section{ABSTRACT}

Fifty-three nonlactating, pregnant Holstein-Friesian and Holstein-Friesian $\times$ Jersey cross dairy cows were grouped into 4 cohorts $(\mathrm{n}=15,12,13$, and 13) and offered 1 of 3 allowances of fresh, cut pasture indoors for $38 \pm 2 \mathrm{~d}$ (mean $\pm \mathrm{SD})$. Cows were released onto a bare paddock after their meal until the following morning. Animals were blocked by age $(6 \pm 2 \mathrm{yr})$, day of gestation $(208 \pm 17 \mathrm{~d})$, and body weight (BW; $526 \pm$ $55 \mathrm{~kg}$ ). The 3 pasture allowances [low: $7.5 \mathrm{~kg}$ of dry matter (DM), medium: $10.1 \mathrm{~kg}$ of DM, or high: 12.4 $\mathrm{kg}$ of DM/cow per day] were offered in individual stalls to determine the estimated DM and metabolizable energy (ME) intake required for zero energy balance. Individual cow DM intake was determined daily and body condition score was assessed once per week. Cow BW was recorded once per week in cohorts 1 and 2 , and 3 times per week in cohorts 3 and 4 . Low, medium, and high allowance treatments consumed 7.5, 9.4, and 10.6 $\mathrm{kg}$ of DM/cow per day [standard error of the difference $(\mathrm{SED})=0.26 \mathrm{~kg}$ of $\mathrm{DM}]$, and $\mathrm{BW}$ gain, including the conceptus, was $0.2,0.6$, and $0.9 \mathrm{~kg} /$ cow per day (SED $=0.12 \mathrm{~kg}$ ), respectively. The ME content of the pasture was estimated from in vitro true digestibility and by near infrared spectroscopy. Total ME requirements for maintenance, pregnancy, and limited activity were 1.07 $\mathrm{MJ}$ of $\mathrm{ME} / \mathrm{kg}$ of measured metabolic BW per day. This is more than $45 \%$ greater than current recommendations. Differences may be due to an underestimation of $\mathrm{ME}$ requirements for maintenance or pregnancy, an overestimation of diet metabolizability, or a combination of these. Further research is necessary to determine the reasons for the greater ME requirements measured in the present study, but the results are important for on-farm decisions regarding feed allocation for nonlactating, pregnant dairy cows.

Key words: maintenance energy, cattle, body weight gain, pregnancy

Received October 17, 2012.

Accepted January 24, 2013.

${ }^{1}$ Corresponding author: kristina.mandok@dairynz.co.nz

\section{INTRODUCTION}

The ME and net energy requirements for cow maintenance, activity, reproduction, and productive purposes have been estimated and are published in energy accounting systems (ARC, 1994; NRC, 2001; CSIRO, 2007). However, recommendations are not always consistent. For example, the NRC (2001) estimates maintenance to be approximately $0.54 \mathrm{MJ}$ of $\mathrm{ME} / \mathrm{kg}$ of $\mathrm{BW}^{0.75}$ for mature lactating cows, assuming a conversion of ME to net energy (the efficiency of use of ME for maintenance; $\mathbf{k}_{\mathbf{m}}$ ) of 0.62 . This includes an additional allowance of $10 \%$ of maintenance for normal activity that is not expended when fasting heat production is measured (i.e., cows in calorimeters). In contrast, the ARC (1994) reported lower ME requirements from fasting heat production experiments with estimated maintenance values for a $500-\mathrm{kg}$ cow of 0.45 to $0.47 \mathrm{MJ}$ of $\mathrm{ME} / \mathrm{kg}$ of $\mathrm{BW}^{0.75}$, at a diet metabolizability of 0.70 or 0.60 , respectively. The CSIRO (2007) developed a more complex prediction equation, incorporating species, sex, age, BW, potential milk production, $\mathrm{k}_{\mathrm{m}}$, energy requirements for grazing activity, and energy expenditure for ambient temperatures below the animal's lower critical temperature. However, actual requirements were not greatly different from those in NRC (2001); for example, a 6-yr-old dairy cow (500 kg of $\mathrm{BW}$ ) in thermoneutral conditions would require 0.56 $\mathrm{MJ}$ of $\mathrm{ME} / \mathrm{kg}$ of $\mathrm{BW}^{0.75}$. The CSIRO (2007) values were used to predict the $\mathrm{ME}$ requirements of grazing dairy cows (Nicol and Brookes, 2007).

In addition to variations between nutrient requirement systems, Yan et al. (1997a,b) reported that ME requirements for maintenance in nonlactating and lactating cows were 12 to $15 \%$ greater than in the studies used to formulate the existing recommendations. These results support the reports by Garrett (1971) and Ferrell and Jenkins (1984) that maintenance ME requirements increase with genetic merit for milk production. Because of this, Nicol and Brookes (2007) increased the $\mathrm{ME}$ requirements for milk production in grazing dairy cows, leaving maintenance at previously recommended levels. Such a change would increase the total ME re- 
quirements of lactating cows, but would not adjust ME requirements in nonlactating cows. This is not consistent with Roche et al. (2005), who reported that ME requirements for maintenance, pregnancy, and activity in nonlactating pregnant dairy cows during the last month of gestation were greater than recommended, at $1.05 \mathrm{MJ}$ of $\mathrm{ME} / \mathrm{kg}$ of $\mathrm{BW}^{0.75}$. Holmes and Grainger (1982) and Grainger et al. (1985) also reported greater requirements for cows grazing autumn pasture in mo 7 precalving (210 to $215 \mathrm{~d}$ of gestation) of up to $1.02 \mathrm{MJ}$ of $\mathrm{ME} / \mathrm{kg}$ of $\mathrm{BW}^{0.75}$, indicating that $\mathrm{ME}$ requirements for maintenance, pregnancy, and activity in nonlactating, grazing cows may be greater than currently recommended. However, in these studies, DMI was only estimated from pre- and postgrazing residuals, and the reported energy requirements were, therefore, only estimates.

The objective of the present study was to determine the ME requirements for zero energy balance of pregnant, nonlactating, grazing dairy cows 2 mo precalving, by accurately measuring DMI, while still exposing cows to conditions similar to those found in grazing systems (i.e., cows were kept on a bare paddock in the afternoon and night).

\section{MATERIALS AND METHODS}

\section{Trial Design and Measurements}

As part of a larger experiment undertaken over $2 \mathrm{yr}$, 53 nonlactating, pregnant Holstein-Friesian and Holstein-Friesian $\times$ Jersey-cross dairy cows were offered 1 of 3 daily pasture allowances for $38 \pm 2 \mathrm{~d}$ (mean $\pm \mathrm{SD}$ ) in 4 cohorts $(\mathrm{n}=15,12,13,13)$ at the DairyNZ Calan Gate (American Calan, Northwood, NH) freestall facility (Hamilton, New Zealand). The 4 cohorts were required because of space limitations in the indoor feeding facilities. Fresh autumn pasture offered was as follows: low $=7.5 \mathrm{~kg}$ of $\mathrm{DM} /$ cow; medium $=10.1 \mathrm{~kg}$ of $\mathrm{DM} /$ cow, and high $=12.4 \mathrm{~kg}$ of $\mathrm{DM} /$ cow. The low allowance was intended to provide the recommended requirements for maintenance based on the measured BW (0.55 MJ of ME $/ \mathrm{kg}$ of BW ${ }^{0.75}$; NRC, 2001; Holmes et al., 2002), with an additional allowance of $20 \mathrm{MJ}$ of $\mathrm{ME} / \mathrm{d}$ for pregnancy and activity (Bell et al., 1995; NRC, 2001).

Before treatment allocation, cows were blocked by age, day of gestation (DOG), and BW. On average, DOG was $208 \pm 17 \mathrm{~d}$, and BW and age were $526 \pm$ $55 \mathrm{~kg}$ and $6 \pm 2 \mathrm{yr}$, respectively. Cows were previously trained to the Calan Gate freestall facility, and all procedures were approved by the Ruakura Animal Ethics Committee. In total, 19, 17, and 17 cows were allocated to the low, medium, and high treatment groups, respectively.
Fresh autumn pasture was cut daily and offered to each cow at $0800 \mathrm{~h}$. Cows had access to the pasture for approximately $7 \mathrm{~h}$, after which they were released onto a neighboring, bare paddock (within $200 \mathrm{~m}$ of the feeding facilities) until the following morning. The amount of daily pasture offered and refused was recorded for individual cows, and representative pasture samples were dried in triplicate at $95^{\circ} \mathrm{C}$ for $48 \mathrm{~h}$ to determine DM content. Individual DMI was calculated as pasture DM offered $(\mathrm{kg})$ minus DM refused $(\mathrm{kg})$. A second sample of offered pasture was dried at $60^{\circ} \mathrm{C}$ for $72 \mathrm{~h}$, ground to pass through a 2.0-mm sieve (Christy Lab Mill, Suffolk, UK), bulked weekly, and analyzed for feed composition and in vitro true DM digestibility (DairyOne, Ithaca, NY). Pasture ME content was estimated from in vitro true $\mathrm{DM}$ digestibility: $\mathrm{ME}=\mathrm{DM}$ digestibility $\times$ $0.172-1.707$ (CSIRO, 2007), as well as determined by near infrared spectroscopy (NIRS) at Hills Laboratory (Hamilton, New Zealand). Feed quality values are reported in Table 1.

In all experimental cohorts, individual BCS (Roche et al., 2004; 10-point scale) was recorded once per week by one experienced assessor. Individual BW was recorded once per week in cohorts 1 and 2 and 3 times per week in cohorts 3 and 4 (Gallagher Smart Scale 500, Hamilton, New Zealand). Calf birth weights were also recorded.

Table 1. Mean ( \pm SD) composition (\% DM, unless otherwise stated) in fresh autumn pasture

\begin{tabular}{|c|c|c|}
\hline Item & Mean & $\mathrm{SD}$ \\
\hline $\mathrm{ME}^{1}(\mathrm{MJ} / \mathrm{kg}$ of $\mathrm{DM})$ & 12.4 & 0.66 \\
\hline $\mathrm{ME}^{2}(\mathrm{MJ} / \mathrm{kg}$ of $\mathrm{DM})$ & 11.3 & 0.60 \\
\hline In vitro true digestibility, $24 \mathrm{~h}$ & 82.0 & 3.81 \\
\hline $\mathrm{CP}$ & 21.7 & 1.68 \\
\hline Crude fat & 4.1 & 0.92 \\
\hline $\mathrm{ADF}$ & 27.8 & 3.89 \\
\hline $\mathrm{NDF}$ & 47.4 & 5.21 \\
\hline NDF digestibility, 24 h ( $\%$ of NDF) & 61.8 & 8.19 \\
\hline Lignin & 4.9 & 1.67 \\
\hline Starch & 1.2 & 0.99 \\
\hline Ethanol-soluble carbohydrates & 7.8 & 2.87 \\
\hline $\mathrm{Ca}$ & 0.7 & 0.30 \\
\hline $\mathrm{P}$ & 0.4 & 0.09 \\
\hline $\mathrm{Mg}$ & 0.2 & 0.02 \\
\hline $\mathrm{K}$ & 3.1 & 0.38 \\
\hline $\mathrm{Na}$ & 0.3 & 0.15 \\
\hline $\mathrm{S}$ & 0.4 & 0.07 \\
\hline $\mathrm{Fe}(\mathrm{mg} / \mathrm{kg})$ & 221.0 & 147.60 \\
\hline $\mathrm{Zn}(\mathrm{mg} / \mathrm{kg})$ & 37.9 & 7.27 \\
\hline $\mathrm{Cu}(\mathrm{mg} / \mathrm{kg})$ & 7.0 & 1.02 \\
\hline $\operatorname{Mn}(\mathrm{mg} / \mathrm{kg})$ & 69.9 & 17.71 \\
\hline Mo (mg/kg) & 0.8 & 0.93 \\
\hline Ash & 10.2 & 1.30 \\
\hline DCAD (mEq/100 g) & 31.6 & 13.05 \\
\hline
\end{tabular}

${ }^{1}$ Estimated using in vitro true digestibility (wet chemistry: DairyOne, Ithaca, NY).

${ }^{2}$ Determined by near infrared spectroscopy. 


\section{Calculations and Statistical Analyses}

The profile of conceptus growth $(\mathrm{kg} / \mathrm{d})$ and ME requirements of the gravid uterus were estimated from calf birth weight using the equations reported by Bell et al. (1995):

$$
\operatorname{GUW}(\mathrm{kg} / \mathrm{d})=(0.664 \times \mathrm{DOG}-102) \times(\mathrm{CBW} / 46),
$$

$$
\begin{aligned}
& \text { and GUER }(\mathrm{MJ} \mathrm{ME} / \mathrm{d})=\left(\left\{\left[0.00159 \times \mathrm{DOG}^{2}\right.\right.\right. \\
& -0.0352 \times \mathrm{DOG}-35.4] \times 4.186 \times \mathrm{CBW} / 46\} \\
& -\left\{\left[0.00159 \times(\mathrm{DOG}-1)^{2}-0.0352 \times(\mathrm{DOG}-1)\right.\right. \\
& -35.4] \times 4.186 \times \mathrm{CBW} / 46\}) / 0.14,
\end{aligned}
$$

where GUW = gravid uterus weight, DOG = day of gestation, CBW = calf birth weight $(\mathrm{kg})$, and GUER $=$ gravid uterus energy requirements. The assumed efficiency of use of ME for conceptus metabolism $\left(\mathbf{k}_{\mathbf{p}}\right)$ was 0.14 (Ferrell et al., 1976; NRC, 2001). Activity requirements were calculated from Nicol and Brookes (2007).

Energy requirements for activity, estimated as 0.0037 MJ of $\mathrm{ME} / \mathrm{kg}$ of $\mathrm{BW}$ per horizontal kilometer walked (Nicol and Brookes, 2007), were $2 \mathrm{MJ}$ of $\mathrm{ME} / \mathrm{d}$, assuming the cows walked $1 \mathrm{~km}$ per day. The ME requirements for pregnancy and activity were added to the basic maintenance (0.55 MJ of ME/ $\mathrm{kg}$ of measured $\mathrm{BW}^{0.75}$ ) to obtain an estimate of the predicted feed allowance for zero energy balance.

Average BW gain/day for each cow was estimated by regressing BW against day using linear models. Individual daily ME intake was calculated as the product of estimated pasture ME and daily DMI for individual cows within each cohort. Associations between mean $\mathrm{ME}$ intake and $\mathrm{BW}$ change, and between mean $\mathrm{ME}$ intake $/ \mathrm{kg}$ of $\mathrm{BW}^{0.75}$ and $\mathrm{BW}$ change were calculated using linear models by fitting a regression line with BW change as the dependent variable and daily ME intake and $\mathrm{ME}$ intake $/ \mathrm{kg}$ of $\mathrm{BW}^{0.75}$ as independent variables. To obtain daily ME requirements for zero energy balance, ME intakes and $\mathrm{ME}$ intakes $/ \mathrm{kg}$ of $\mathrm{BW}^{0.75}$ were calculated from the fitted equations by taking into account the estimated daily weight gain of the gravid uterus.

Differences in genetic merit were analyzed by dividing cows into 3 groups for breeding worth (low, medium, and high breeding worth). This grouping and its interaction with the independent variables were included in the regression analysis.

\section{RESULTS AND DISCUSSION}

Based on average calf birth weight $(39 \pm 7 \mathrm{~kg})$, the estimated gravid uterus weight and daily gravid uterus weight change at $208 \mathrm{~d}$ of gestation were $30.1 \pm 9.1 \mathrm{~kg}$ and $0.6 \pm 0.13 \mathrm{~kg}$, respectively. Average ME content of the pasture offered was $11.9 \pm 0.38,12.7 \pm 0.21,12.5$ \pm 0.96 , and $12.8 \pm 0.17$ for cohorts 1 to 4 , respectively. Pasture composition and ME are presented in Table 1. Dry matter intake, ME intake, and BW and BCS data for cows receiving the low, medium, and high allowances are presented in Table 2.

Average DMI and ME intake (average $\pm \mathrm{SE}$ ) associated with zero BW change were $6.9 \pm 0.32 \mathrm{~kg} / \mathrm{d}$ and 86 $\pm 3.93 \mathrm{MJ} / \mathrm{d}$, respectively. However, zero BW change does not account for growth of the gravid uterus. Following adjustment for gravid uterus weight change (0.6 $\mathrm{kg} / \mathrm{d}$ ), ME intake associated with zero energy balance of the dam was $117 \pm 2.6 \mathrm{MJ} / \mathrm{d}\left(\mathrm{R}^{2}=0.63\right.$; Figure $\left.1 \mathrm{a}\right)$. This resulted in total ME requirements of $1.07 \pm 0.025$ $\mathrm{MJ}$ of $\mathrm{ME} / \mathrm{kg}$ of measured $\mathrm{BW}^{0.75}$ for maintenance, activity, and pregnancy $\left(\mathrm{R}^{2}=0.56\right.$; Figure $\left.1 \mathrm{~b}\right)$. Daily pregnancy ME requirements were estimated to be 15.8 MJ of ME (see Equation [2]), which is similar to the reported ME requirements at this stage of gestation for

\begin{tabular}{|c|c|c|c|c|c|}
\hline \multirow[b]{2}{*}{ Item } & \multicolumn{3}{|c|}{ Treatment $^{1}$} & \multirow[b]{2}{*}{$\mathrm{SED}^{2}$} & \multirow[b]{2}{*}{$P$-value } \\
\hline & Low & Medium & High & & \\
\hline DMI $(\mathrm{kg}$ of $\mathrm{DM} / \mathrm{d})$ & 7.5 & 9.4 & 10.6 & 0.26 & $<0.001$ \\
\hline ME intake/d (MJ of ME) & 94.6 & 118.0 & 133.1 & 3.17 & $<0.001$ \\
\hline $\mathrm{BW}$ change/d $(\mathrm{kg})$ & 0.22 & 0.59 & 0.89 & 0.117 & $<0.001$ \\
\hline BCS change (units $\times 10^{-2} / \mathrm{d}$ ) & 1.0 & 1.4 & 1.7 & 0.30 & $<0.05$ \\
\hline
\end{tabular}
pasture-based cows carrying a 40-kg calf (15 to $20 \mathrm{MJ}$ of ME/d; Nicol and Brookes, 2007).

Table 2. Pasture DMI, ME intake, daily BW change, and BCS change for cows on low, medium, and high pasture allowances

${ }^{1}$ Low $=$ estimated maintenance $\left(0.55 \mathrm{MJ}\right.$ of $\mathrm{ME} / \mathrm{kg}$ of $\left.\mathrm{BW}^{0.75}\right)$ plus a $20 \mathrm{MJ}$ of ME allowance for pregnancy and limited activity; medium $=$ low pasture allowance plus $2.5 \mathrm{~kg}$ of DM offered; high $=$ low pasture allowance plus $5.0 \mathrm{~kg}$ of DM offered.

${ }^{2}$ Standard error of the difference of the means. 

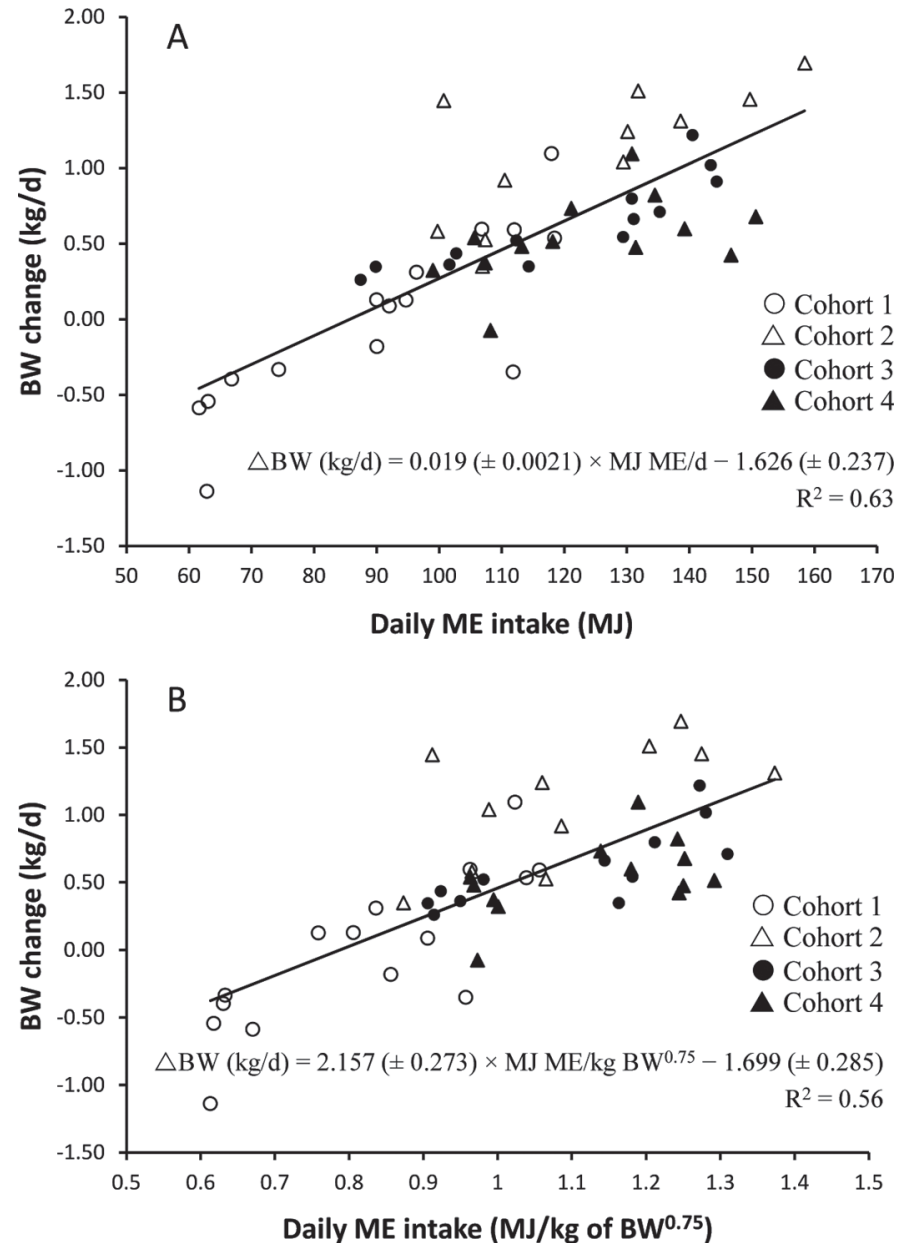

Figure 1. The relationship between (A) ME consumed (MJ/d), and (B) ME consumed per kilogram of metabolic BW (MJ of $\mathrm{ME} / \mathrm{kg}$ of $\mathrm{BW}^{0.75}$ per day) and daily BW change $(\mathrm{kg} / \mathrm{d})$ in nonlactating, pregnant Holstein-Friesian and Holstein-Friesian $\times$ Jersey dairy cows $(526$ $\pm 55 \mathrm{~kg}$ of BW; $208 \pm 17 \mathrm{~d}$ of gestation). Individual standard errors of the regression equations are displayed.

Maintenance requirements are described as the energy required to maintain homeothermy and vital physiological processes at zero energy balance (no tissue gain or loss; ARC, 1994; NRC, 2001). Calorimetry and slaughter studies resulted in estimates for maintenance requirements of $0.43 \mathrm{MJ}$ of $\mathrm{ME} / \mathrm{kg}$ of $\mathrm{BW}^{0.75}$ (Van Es, 1961; Moe and Tyrrell, 1972; ARC, 1994). These requirements were increased to 0.55 to $0.58 \mathrm{MJ}$ of $\mathrm{ME} / \mathrm{kg}$ of $\mathrm{BW}^{0.75}$ for nonlactating grazing dairy cows and to 0.60 to $0.67 \mathrm{MJ}$ of $\mathrm{ME} / \mathrm{kg}$ of $\mathrm{BW}^{0.75}$ for lactating grazing dairy cows (Holmes et al., 2002; Nicol and Brookes, 2007), which are consistent with NRC (2001) recommendations.

The results obtained in this study suggest ME requirements for maintenance, pregnancy, and activity of $1.07 \mathrm{MJ}$ of $\mathrm{ME} / \mathrm{kg}$ of $\mathrm{BW}^{0.75}$ (or $117 \mathrm{MJ}$ of $\mathrm{ME} / \mathrm{d}$ ). Using published literature to estimate ME require- ments for maintenance $(0.55-0.58 \mathrm{MJ}$ of $\mathrm{ME} / \mathrm{kg}$ of $\mathrm{BW}^{0.75}=$ approximately $60 \mathrm{MJ}$ of $\mathrm{ME} / \mathrm{d}$ ) and adding $\mathrm{ME}$ requirements for pregnancy and activity (approximately $20 \mathrm{MJ}$ of $\mathrm{ME} / \mathrm{d}$ ), total $\mathrm{ME}$ requirements for zero energy balance of the dam would be approximately $80 \mathrm{MJ}$ of $\mathrm{ME} / \mathrm{d}$ (i.e., $0.73 \mathrm{MJ}$ of $\mathrm{ME} / \mathrm{kg}$ of $\mathrm{BW}^{0.75}$ ). This suggests that current ME recommendations underestimate the requirements for zero energy balance of nonlactating grazing dairy cows in mid to late gestation by approximately $45 \%$. These greater $\mathrm{ME}$ requirements are consistent with Roche et al. (2005), who reported that $1.05 \mathrm{MJ}$ of $\mathrm{ME} / \mathrm{kg}$ of $\mathrm{BW}^{0.75}$ was needed to maintain zero energy balance in grazing dairy cows 1 mo before calving, and with Holmes and Grainger (1982) and Grainger et al. (1985), who reported values of up to $1.02 \mathrm{MJ}$ for cows grazing autumn pasture and 0.71 $\mathrm{MJ}$ of $\mathrm{ME} / \mathrm{kg}$ of $\mathrm{BW}^{0.75}$ for cows fed fresh pasture indoors, respectively, at a stage of gestation similar to that of the present study. The reason for the greater ME requirements is not known; however, the most plausible reasons include inaccuracies in the previous recommendations in determining the metabolizability of the diet, errors associated with feed ME determination, differences in ME requirements for maintenance and pregnancy across breeds and genetic strains, and differences in the efficiency with which ME from different feeds is used for different physiological processes.

\section{Diet Metabolizability}

Some of the difference between results reported here and previous recommendations may be due to physiological state and the effect that this has on diet metabolizability. Moe et al. (1970) and Yan et al. (1997) reported that the efficiency of use of energy for tissue gain was 18 to $20 \%$ lower in nonlactating cows compared with lactating cows; this could be due to an increase in the intestinal passage rate of the digesta in late gestation, resulting in decreased digestibility of some feeds (Graham and Williams, 1962). The use of in vitro DM digestibility to calculate ME may, therefore, overestimate pasture ME for nonlactating cows. When using the ME obtained from near infrared spectroscopy analysis (Table 1), ME requirements for zero energy balance decreased to $0.97( \pm 0.191) \mathrm{MJ}$ of $\mathrm{ME} / \mathrm{kg}$ of $\mathrm{BW}^{0.75}$, but this is still more than $30 \%$ higher than requirements proposed in the literature. Moreover, when the estimated ME of pasture was reduced by the $18 \%$ reported by Moe et al. (1970) and Yan et al. (1997), pasture ME would decrease from 12.4 to $10.2 \mathrm{MJ} / \mathrm{kg}$ of DM. This would be unexpectedly low for green leafy pastures (Roche et al., 2009) and still would not account for the total difference between the ME requirements reported in the present study, and by Roche et 
al. (2005) and Holmes and Grainger (1982), and those previously recommended (ARC, 1994; NRC, 2001; Holmes et al., 2002; Nicol and Brookes, 2007). Even with a reduced ME of pasture, the results presented here indicate that ME requirements for maintenance, pregnancy, and limited activity are 30\% higher than previously recommended. Therefore, other contributing factors must exist.

In a study on heifers, Reynolds et al. (1991) reported differences in heat production and tissue energy retention with changing diet composition, even though ME intake was equal between treatment groups. Variances in the metabolizability of a particular diet might alter $\mathrm{k}_{\mathrm{m}}$. Hence, values reported for TMR-based systems may not be applicable for grazing dairy cows.

Another possible reason for the inconsistency in published estimates of ME requirements may relate to the method of their determination. For example, Larson and Johnson (1997) reported greater efficiencies of use of energy for BW gain from calorimetry experiments (fasting animals) than from slaughter experiments. This was presumed to be due to the short duration of calorimetry studies and the fact that energy from BW loss is used more efficiently than dietary energy (ARC, 1994). Use of energy from imperceptible BW loss in short-term calorimetry studies may explain some of the inconsistencies in reported requirements.

\section{Maintenance}

Metabolizable energy is used less efficiently for BW gain in autumn pasture than in spring pasture (Rook, 1964) or in alternative feeds such as maize silage and concentrate supplements (Mandok et al., 2012). It is plausible, therefore, that $\mathrm{k}_{\mathrm{m}}$ is also lower in autumn pasture, which would explain at least some of the increased ME requirements reported here and by Roche et al. (2005) and Grainger et al. (1985), compared with alternative diets.

A further reason for the inconsistencies in recommended ME requirements for zero energy balance may relate to genetic differences in maintenance energy requirements. Ferrell and Jenkins (1984) reported that higher milk-yield breeds required over $20 \%$ more ME for maintenance than lower milk-yield breeds. In addition, Garrett (1971) reported that Hereford steers needed less ME for maintenance than Holstein-Friesian steers and were $12 \%$ more efficient in converting $\mathrm{ME}$ above maintenance into BW gain. These data indicate that $\mathrm{k}_{\mathrm{m}}$ may be affected by cow genetics and, in particular, that selection toward greater milk production may increase maintenance ME requirements. We found no differences between $\mathrm{k}_{\mathrm{m}}$ of cows with low or high genetic merit in the current experiment. However, it is still plausible that the genetic strain of the cows used in this study had greater maintenance requirements than strains used in previous experiments, and further research should be undertaken to test this hypothesis in both grazing and TMR-based dairy systems.

\section{Pregnancy}

Net energy requirements for conceptus metabolism $\left(\mathrm{k}_{\mathrm{p}}\right)$ are estimated from slaughter studies (Rattray et al., 1974; Garrett and Johnson, 1983) and heat production experiments. There is general agreement that $\mathrm{k}_{\mathrm{p}}$ in ruminant species is low (NRC, 2001; CSIRO, 2007). Battaglia and Meschia (1978) reported differences in the permeability of the placenta to FFA, including short-chain fatty acids such as acetate. Acetate is the major energy substrate in the grazing, adult ruminant, but it can only cross the ruminant placenta in very limited amounts. This results in a relatively inefficient use of $\mathrm{ME}$ for conceptus metabolism. All energy systems have adopted a similar $\mathrm{k}_{\mathrm{p}}(0.13-0.14$; ARC, 1994; NRC, 2001; CSIRO, 2007), irrespective of diet. However, reports on the effect of physiological state and diet quality on the $k_{\mathrm{p}}$ in ruminants are inconsistent. Nicol and Brookes (2007) stated that there was no evidence that $\mathrm{k}_{\mathrm{p}}$ changes through gestation or with the quality of the diet. Other researchers, however, have reported that DMI and metabolizability of the diet do affect $\mathrm{k}_{\mathrm{p}}$ (Rook, 1964; Yan et al., 1997; Roche et al., 2005). In support of this, Robinson et al. (1980) reported a $20 \%$ reduction in $\mathrm{k}_{\mathrm{p}}$ in pregnant sheep when ME intake decreased from 15 to $12 \mathrm{MJ}$ of ME/d. This is consistent with Hutchings (1997), who predicted variation in the efficiency with which ME is used for conceptus metabolism (from 0.11 to 0.18 ) with changing diet metabolizability (from 0.40 to 0.80 ). Robinson et al. (1999) proposed similar differences in $\mathrm{k}_{\mathrm{p}}$ (i.e., from 0.11 to 0.17 ) with increasing feed quality. Although autumn pasture is not particularly low in gross energy, considerable evidence suggests that it is used inefficiently for BW gain in ruminant species (Macrae et al., 1985; CSIRO, 2007). These data reflect deficiencies in autumn pasture that are not evident in standard laboratory analyses. Therefore, it is plausible that $\mathrm{k}_{\mathrm{p}}$ is also less for autumn pasture, although further research is required to verify or refute this hypothesis.

\section{CONCLUSIONS}

Recommended ME requirements for zero energy balance of nonlactating, pregnant dairy cows fed fresh pasture are too low. Measurements reported here and by others indicate that values should be increased by 30 to $45 \%$. Reasons for the difference between measured and recommended values are not clear, but the differ- 
ence could be due to increased maintenance requirements in cattle selected for greater milk production, an underestimation of the ME requirements for pregnancy in mid to late gestation, an overestimation of the $\mathrm{ME}$ content of autumn pasture, or low efficiency of use of ME from autumn pasture for maintenance or conceptus metabolism. Even if the estimated ME content of pasture used in these calculations was too high, it would not fully explain the discrepancy between predicted and measured values. The effect of cow genetics and diet (i.e., supplementation or TMR) on the efficiency of ME use for maintenance and conceptus metabolism must be investigated. The current study does not allow the separation of maintenance and pregnancy requirements and this should be a focus of future research in this area. Nonetheless, at a dairy producer level, the greater requirements must be accounted for in feed budgeting.

\section{ACKNOWLEDGMENTS}

The authors thank DairyNZ technical and farm staff for their help during feeding and sample collection. DairyNZ Inc. (project nos. AN803 and AN1010) and the Ministry of Primary Industries New Zealand, through the Sustainable Farming Fund (Project No. 08/012), provided financial support. The assistance of Barbara Dow (Dairy NZ Inc.) with statistical analysis and interpretation is gratefully acknowledged.

\section{REFERENCES}

ARC. 1994. Requirements for energy. Pages 73-119 in The Nutrient Requirements of Ruminant Livestock. M. Freer, ed. Agricultural Research Council, CAB International, Wallingford, UK.

Battaglia, F. C., and G. Meschia. 1978. Principal substrates of fetal metabolism. Physiol. Rev. 58:499-527.

Bell, A. W., R. Slepetis, and R. A. Ehrhardt. 1995. Growth and accretion of energy and protein in the gravid uterus during late pregnancy in Holstein cows. J. Dairy Sci. 78:1954-1961.

CSIRO. 2007. Nutrient Requirements of Domesticated Ruminants. M. Freer, H. Dove, and J. V. Nolan, ed. Commonwealth Scientific and Industrial Research Organisation (CSIRO), Collingwood, Australia.

Ferrell, C. L., W. N. Garrett, N. Hinman, and G. Grichting. 1976. Energy utilization by pregnant and non-pregnant heifers. J. Anim. Sci. 42:937-950.

Ferrell, C. L., and T. G. Jenkins. 1984. Energy utilization by mature, nonpregnant, nonlactating cows of different types. J. Anim. Sci. 58:234-243.

Garrett, W. N. 1971. Energetic efficiency of beef and dairy steers. J. Anim. Sci. 32:451-456.

Garrett, W. N., and D. E. Johnson. 1983. Nutritional energetics of ruminants. J. Anim. Sci. 57:478-497.

Graham, N. M., and A. Williams. 1962. The effects of pregnancy of the passage of food through the digestive tract of sheep. Aust. J. Agric. Res. 13:894-900.

Grainger, C., C. W. Holmes, and Y. F. Moore. 1985. Performance of Friesian cows with high and low breeding indexes. 2. Energy and nitrogen balance experiments with lactating and pregnant, nonlactating cows. Anim. Sci. 40:389-400.
Holmes, C. W., I. M. Brookes, D. J. Garrick, D. D. S. Mackenzie, T. J. Parkinson, and G. F. Wilson. 2002. Nutrition: Quantitative requirements of dairy cattle. Pages 235-262 in Milk Production from Pasture. D. Swain, ed. Massey University, Palmerston North, New Zealand.

Holmes, C. W., and C. Grainger. 1982. Some estimates of the pasture required to maintain and gain body condition of dry, pregnant dairy cows. Pages $172-173$ in Dairy Production from Pasture. K. L. Macmillan and V. K. Taufa, ed. New Zealand Society of Animal Production, Hamilton, New Zealand.

Hutchings, N. J. 1997. Estimating the metabolizable energy requirement for pregnancy in sheep. Anim. Sci. 64:463-467.

Larson, E. M., and D. E. Johnson. 1997. Predicting net energy of feedstuffs for beef cattle. Pages 355-362 in Energy Metabolism of Farm Animals. K. McCracken, E. F. Unsworth, and A. R. G. Wylie, ed. CAB International, Wallingford, UK.

Macrae, J. C., J. S. Smith, P. J. S. Dewey, A. C. Brewer, D. S. Brown, and A. Walker. 1985. The efficiency of utilization of metabolisable energy and apparent absorption of amino acids in sheep given spring- and autumn-harvested dried grass. Br. J. Nutr. 54:197209.

Mandok, K. S., J. K. Kay, S. L. Greenwood, G. R. Edwards, M. Crookenden, and J. R. Roche. 2012. The efficiency with which metabolisable energy is used for live weight gain differs between feed. Pages 338-342 in Proc. Australasian Dairy Sci. Symp., Melbourne, Australia. Australian Dairy Science Symposium, Tallygaroopna, Victoria, Australia

Moe, P. W., and H. F. Tyrrell. 1972. Metabolizable energy requirements of pregnant dairy cows. J. Dairy Sci. 55:480-483.

Moe, P. W., H. F. Tyrrell, and W. P. Flatt. 1970. Partial efficiency of energy use for maintenance, lactation, body gain and gestation in the dairy cow. Pages 65-68 in Energy Metabolism of Farm Animals. Vol. 13. A. Schürch and C. Wenk, ed. Eur. Assoc. Anim. Prod., Zurich, Switzerland.

Nicol, A. M., and I. M. Brookes. 2007. The metabolisable energy requirements of grazing livestock. Pages 151-172 in Pasture and supplements for grazing dairy cattle. Vol. 14. P. V. Rattray, I. M. Brookes, and A. M. Nicol, ed. New Zealand Society of Animal Production, Hamilton, New Zealand.

NRC. 2001. Nutrient Requirements of Dairy Cattle. 7th ed. National Academy of Science, Washington, DC.

Rattray, P. V., W. N. Garrett, N. E. East, and N. Hinman. 1974. Efficiency of utilization of metabolizable energy during pregnancy and the energy requirements for pregnancy in sheep. J. Anim. Sci. 38:383-393.

Reynolds, C. K., H. F. Tyrrell, and P. J. Reynolds. 1991. Effects of diet forage-to-concentrate ratio and intake on energy-metabolism in growing beef heifers: Whole-body energy and nitrogen-balance and visceral heat-production. J. Nutr. 121:994-1003.

Robinson, D. L., A. J. Sinclair, R. D. Randel, and A. R. Sykes. 1999. Nutritional management of the female ruminant: Mechanistic approaches and predictive models. Pages 530-608 in Proc. Nutritional Ecology of Herbivores. American Society of Animal Science, Champaign, IL.

Robinson, J. J., I. McDonald, C. Fraser, and J. G. Gordon. 1980. Studies on reproduction in prolific ewes. 6 . The efficiency of energy-utilization for conceptus growth. J. Agric. Sci. (Camb.) 94:331-338.

Roche, J. R., P. G. Dillon, C. R. Stockdale, L. H. Baumgard, and M. J. VanBaale. 2004. Relationships among international body condition scoring systems. J. Dairy Sci. 87:3076-3079.

Roche, J. R., E. S. Kolver, and J. K. Kay. 2005. Influence of precalving feed allowance on periparturient metabolic and hormonal responses and milk production in grazing dairy cows. J. Dairy Sci. 88:677-689.

Roche, J. R., L. R. Turner, J. M. Lee, D. C. Edmeades, D. J. Donaghy, K. A. Macdonald, J. W. Penno, and D. P. Berry. 2009. Weather, herbage quality and milk production in pastoral systems. 2. Temporal patterns and intra-relationships in herbage quality and mineral concentration parameters. Anim. Prod. Sci. 49:200-210.

Rook, J. A. 1964. Ruminal volatile fatty acid production in relation to animal production from grass. Proc. Nutr. Soc. 23:71-80. 
Van Es, A. J. H. 1961. Between-animal variation in the amount of energy required for the maintenance of cows. Doctoral Diss. Laboratory of Physiology, Wageningen Agricultural College, Wageningen, the Netherlands.

Yan, T., F. J. Gordon, R. E. Agnew, M. G. Porter, and D. C. Patterson. 1997a. The metabolisable energy requirement for maintenance and the efficiency of utilisation of metabolisable energy for lacta- tion by dairy cows offered grass silage-based diets. Livest. Prod. Sci. 51:141-150.

Yan, T., F. J. Gordon, C. P. Ferris, R. E. Agnew, M. G. Porter, and D. C. Patterson. 1997b. The fasting heat production and effect of lactation on energy utilisation by dairy cows offered forage-based diets. Livest. Prod. Sci. 52:177-186. 